\title{
BUFFER ZONE OF THE SINHARAJA BIOSPHERE RESERVE IN SRI LANKA AND ITS MANAGEMENT STRATEGIES
}

\author{
W. A. D. A. WIJESOORIYA ${ }^{1}$ and C. V. S. GUNATILLEKE ${ }^{2 *}$ \\ ${ }^{1}$ Forest Department, Sri Lanka \\ ${ }^{2}$ Dept. of Botany, Faculty of Science, University of Peradeniya, Sri Lanka
}

\begin{abstract}
Proceedings of the South and Central Asian MAB Meeting of Experts on Environmental Conservation, Management and Research, Hikkaduwa, Sri Lanka 15-18 October 2002
\end{abstract}

Summary: The three $\mathrm{km}$ wide Sinharaja buffer zone, falling within the districts of Ratnapura, Galle and Matara, includes natural forests, Pinus caribaea plantations since the late 1970's, non-forested land, tea plantations especially on its southeastern and western sides, private land and village home gardens. Its socioeconomic aspects are governed by over 40 ancient, satellite or new villages, two of which are within its boundary. It has a population of over 26,000 people in about 6,500 families that now have well-constructed houses. Since the early 1980's, most villagers cultivate tea in their home gardens, because of its high returns. In the past, many generations of villagers used Sinharaja as a supermarket, from where they gathered products from about 179 useful plant species, 33\% of which are endemic, for their subsistence and their market economy.

The strategies adopted for the buffer zone management of Sinharaja include the following: a) Conservation awareness programmes among villagers, which have led to the formation of a community level youth organization named "Sinharaja Sumithuro" or "Friends of Sinharaja' which now participates in conservation activities, b) Publicity on Sinharaja, through the media and through school-level essay and art competitions, consequently, visitors to the reserve now average about 25,000 per annum, c) Community support through upgrading educational facilities in rural schools, organizing medical health camps and improving village roads, d) Adaptive research where monoculture Pinus plantations have been enriched with multiple use, high demanding forest species, e) Alternate income-generation and increase in agricultural productivity by bringing experts to advice villagers on the cultivation of tea and also by training village youth to serve as visitor guides. With the influx of visitors, boutiques which supply their needs and even a few private accommodation facilities run by the villagers have been developed, f) Facilitating timber production and other forest products through the distribution of tree seedlings of popular timber species for planting in home gardens, and by supporting school nurseries, g) Promoting and regulating non-destructive use of forest products, other than timber. Through these activitiés the Forest Department has come closer to the people.

If the species and genetic diversity endemic to the island are to be conserved in the longterm, the wet zone lowland rain forests must be managed and conserved as one entity. It is this knowledge that has prompted the Forest Department to manage clusters of forests. We hope that in due course this will also lead to linking them through their respective buffer zones and through other reservations like stream, catchment and road reservations, so that this country will have a true and effective

\footnotetext{
${ }^{*}$ Corresponding author
} 
network of protected areas and not a system of isolated fragmented and ineffective

biological reserves.

\section{Introduction}

The term buffer zone has been variously defined. For the purpose of this paper we have adopted that by Mackinnon, ${ }^{10}$ who describes it as "areas peripheral to national parks or reserves, which have restrictions placed on their use, to give an added layer of protection to the nature reserve itself and to compensate villagers for the loss of access to strict reserve areas". Embodied in the buffer zone concept are three desirable effects; firstly, to encourage the partnership of the local people to manage the core area, secondly to retain desirable features of the landscape created by human use, and thirdly to facilitate animal dispersal and gene flow between highly protected, fragmented and isolated core conservation areas and human dominated transitional unprotected areas..$^{15}$ It is an area where traditional human activities are permitted and non-destructive research is conducted. Ideally, surrounding the buffer zone should also be a transitional zone where some forms of sustainable development are allowed, along with some extraction of natural resources and experimental research.

\section{The Sinharaja Buffer Zone}

Around the periphery of the Sinharaja Biosphere Reserve, a $3 \mathrm{~km}$ wide buffer zone has been established to reduce resource demands on the reserve and to help prevent human encroachment. The buffer zone includes natural forests, Pinus caribaea plantations, non-forested land, private land and village home gardens. All other lands in the buffer zone are state owned. Most of the forested lands are administered by the Forest Department and a few small areas by state agencies like the State Plantation Corporation. The buffer zone is protected under the legislation of the Forest Ordinance as Other State Forests. This not only permits activities such as collection of non-timber forest products in the buffer zone, but also seeks to regulate them. ${ }^{4}$

In this paper, we examine the buffer zone of the Sinharaja Man and the Biosphere Reserve in terms of (i) the villages and its people, (ii) other land uses and (iii) management strategies adopted by the Forest Department - all of which provide insights into the first and second effects of the buffer zone concept - and (iv) research and extension conducted in this area, which among other desirable features aim at facilitating gene flow among undisturbed primary forests and man-influenced ecosystems. The information presented here, except where references are cited, has been obtained from the Management Plan for the Conservation of the Sinharaja Forest (Phase II), the annual reports and other internal reports of the Forest Department. 


\section{The Villages and their People}

The socioeconomic aspects of the Sinharaja buffer zone are governed by 30 villages, dotted mostly around the perimeter of the reserve with two inside its boundary.

Among the 30 villages, some are as old as 100 years; of them 28 are gazetted and two are not gazetted. They have also been classified as ancient villages (Giguruwa, Kosmulla, Kolontotuwa, etc.), satellite villages of more recent origin (e.g. Penikoladeniya, Indigaswila, Ilumbekande, Denuwakkanda, etc.) and newly formed ones (e.g. Sinhagama). The two most ancient villages are Kosmulle and Pitakelle, which date back to the times of the Sinhalese kings several centuries ago. District wise, 12 villages belong to the Ratnapura District, 12 to the Galle District and 6 to the Matara District (Fig. 1, Table 1). The eastern, northeastern, southeastern and the southwestern parts of the buffer zone do not have any villages. With the exception of Pitakelle in the northwestern border of the reserve, 12 villages are located along the northern border and 17 along the southern border.

Table 1: Some of the ancient (A), satellite (S) and new villages in the Districts of Galle (G), Ratnapura (R) and Matara (M), around the immediate perimeter of the Sinharaja Biosphere Reserve and International Man and the Biosphere Reserve.

\begin{tabular}{llcrlc}
\hline & Village & District & & Village \\
Name & Nype & & Name & $\begin{array}{c}\text { District } \\
\text { \& Type }\end{array}$ \\
\hline 1 & Ihala Giguruwa & G,A & 16 & Kiriweldola & M,A \\
2 & Pahala Giguruwa & G,A & 17 & Hinguruhena & M,S \\
3 & Kosmulla & G,A & 18 & Sinhagama & M,N \\
4 & Thambalagama & G,S & 19 & Illumbakanda & R,S \\
5 & Kabaragala & G,S & 20 & Denuwakkanda & R,S \\
6 & Indigasvilla & G,S & 21 & Dhamgahamulla & R \\
7 & Panikoladeniya & G,S & 22 & Halpantenna & R,S \\
8 & Warukandeniya & G,A & 23 & Madiringawatta & R,S \\
9 & Walugederagama & G,S & 24 & Pothupitiya & R,A \\
10 & Kolonthotuwa & G,A & 25 & Pellawatta South & R \\
11 & Lankagama & G,A & 26 & Koskulana & R \\
12 & Watugala & G,A & 27 & Kongahakanda & R \\
13 & Kohilarambe & M & 28 & Ketalapattala & R \\
14 & Mederipitiya & M,A & 29 & Kudawa & R,A \\
15 & Kiriwalgama & M,A & 30 & Pitakelle & R,A \\
\hline
\end{tabular}




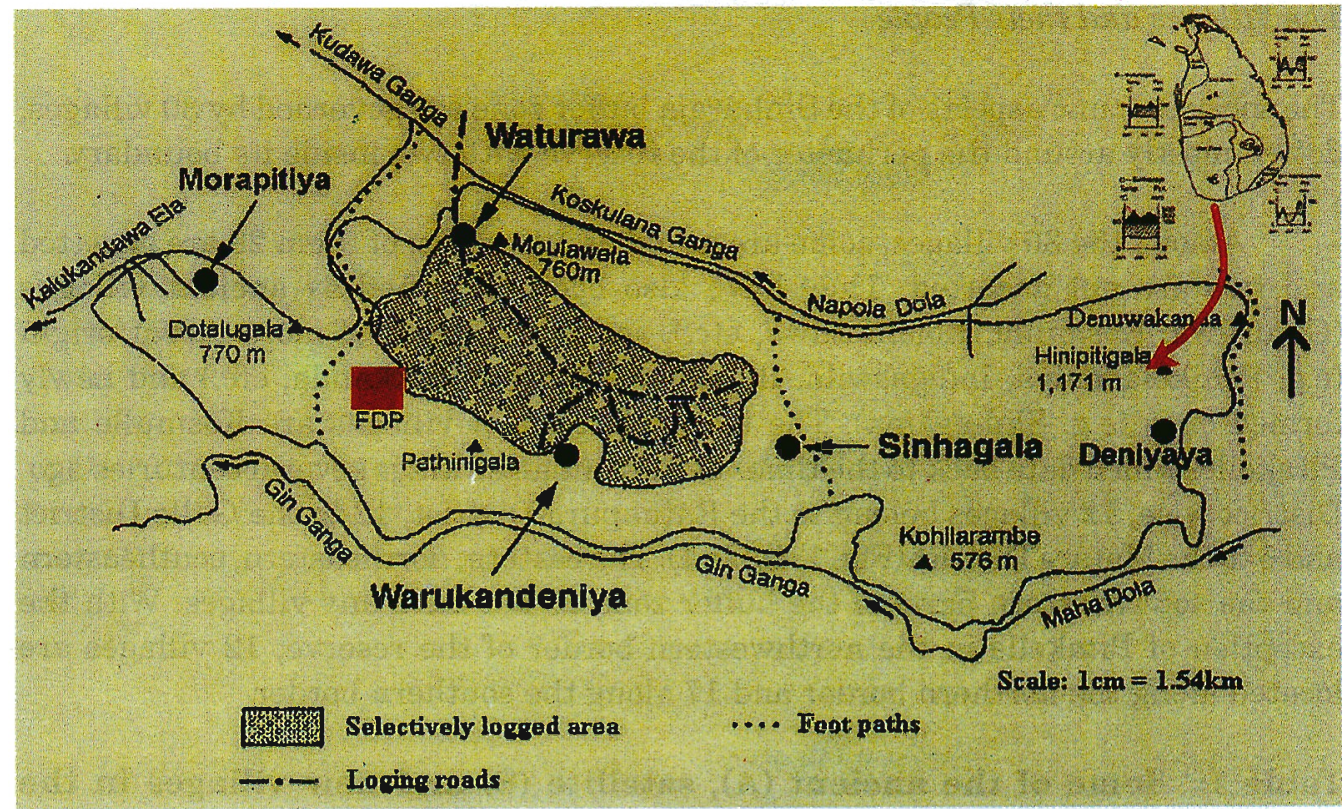

Figure 1: Location of Sinharaja International Man and the Biosphere Reserve (without the extension in the eastern part) within Sri Lanka showing the rivers and streams that demarcate its northern, southern and southwestern boundaries, major peaks (triangles) and locations of longterm study sites $\square / 0$ (red square and black circles)

Population: Based on records of "Grama Niladharis" (the government administrative officers at village level) over 40 villages around the Sinharaja had a resident population of about 26,000 persons, in 6,500 families, ranging between 42 to 429 households per village. The number of persons per family was a little over 5 .

Housing: Most of the villagers now live in well constructed houses with permanent walls and roofs. During field observations of the Forest Department in 1989, only two houses were observed to be thatched with 'Beru' leaves (Agrostistachys intramarginalis), one in Watugala and the other in Pitakele. In the seventies, most of the houses were constructed with local materials, wattle and daub for the walls and leaves such as 'Beru', 'Bata' (Ochlandra stridula), Coconut (Cocos nucifera) and paddy straw for the roofs.

Occupation: The main occupation of the people around Sinharaja is agriculture. In the past, this had mostly been shifting cultivation in the uplands, and on a smaller scale, cultivation of tea, rubber, coconut and cinnamon. The low-lying areas were cultivated with paddy in the past, but now only those in the south continue to be cultivated, whereas those in the north have been abandoned, some due to devastation of crops by wild boar and other animals, and others due to difficulties in their 
management. The cultivation of vegetables and raising of livestock have hardly ever been attempted by these villagers.

A survey of $50 \%$ of the households in Kudawa and Pitakelle in the north western part of the buffer zone, by Kathriarachchi ${ }^{9}$ also revealed that $46-59 \%$ of the households had home gardens of $0.1-0.4$ ha, $95-100 \%$ had tea as a commercial crop, $61-85 \%$ extracted resources from the forest, 29 - $77 \%$ tapped Caryota urens as an income-generating cottage industry, $33-46 \%$ gathered the medicinal vine Coscinium fenestratum for their home consumption.

Tea Small Holdings or Tea Gardens: Since the early 1980's, most villagers have taken up the cultivation of tea in their home gardens. The assurance of a good income on a year round basis, the availability of government subsidies for tea small holdings, a well developed collection and transport system for fresh leaf directly from the village, the supply of fertilizer and other chemicals by the transporting agent direct to the villager at his request, have all resulted in making tea a lucrative crop for villagers. The extensive shifting cultivation lands of the past, around the Sinharaja reserve, have now given way to these tea gardens.

The problems encountered by small holder tea growers around Sinharaja have been studied by Wanigasundara et $a l .{ }^{16}$ They have examined the productivity of 38 randomly selected tea small holdings, from three villages, Lankagama, West Batuangala and Kudawe representative of the tea growing regions of Galle, Deniyaya and Ratnapura, respectively. Their results indicate that $42 \%$ of these small holders have not received information from the Tea Small Holding Development Authority; soil erosion in $12 \%$ of the tea gardens was very little, $76 \%$ was low and $12 \%$ was high; and their productivity was significantly higher $(1,880-2,235 \mathrm{~kg} / \mathrm{ha} / \mathrm{year})$ than the national average $(1,600 \mathrm{~kg} / \mathrm{ha} / \mathrm{yr})$. Shot hole borer, blister blight, wood rot; stem canker and live wood termite were among the common pests and diseases observed, and $40 \%$ of the gardens were affected by live wood termites. They also report that management practices (weeding, pruning, plucking and maintenance of bush health) adopted by tea growers could be further improved. At least in the three villages studied by Wanigasundara et al. ${ }^{16}$ there seemed to be lesser soil erosion than was generally stated for the peripheral village tea gardens in the late 1980s and early 1990 s by the field officers who carried out the survey for Phase 11 of the Management Plans for the Conservation of Sinharaja. ${ }^{1}$ They reported, then, that soil fertility in the majority of the lands was poor and was further deteriorating, and that soil erosion was severe, requiring urgent soil conservation measures, particularly on steep lands where tea is cultivated. Crop yield was also reported to be poor, at that time.

Extraction of Non-wood Resources: For many generations, the Sinharaja forest has been a supermarket for villagers living around Sinharaja. In the Sinharaja and surrounding forests, 179 forest species, of which $33 \%$ are endemic, provide forest 
products gathered by villages..$^{7,10,12,13}$ Folk knowledge on the indigenous use of forest products, gathered by surveying 85 people in two villages, Denuwakkanda and Ilumbakanda, bordering Sinharaja, ${ }^{11}$ reveals significant relationships with age, gender, distance to forest and social participation. McDermott ${ }^{12,13}$ studied the extent to which the villagers depended upon forest products for their subsistence and their market economy. The major forest product that villagers depended upon for their economy in the past was the sugar sap of the Fish Tail palm, locally known as 'Kitul' (Caryota urens). The inflorescence sap of this palm is gathered, concentrated and sold as a solid sugar candy known as jaggary, or as a viscous sugary sap or treacle. It is also made into a alchoholic beverage, locally called toddy. Other products that have been gathered from the forest are rattan, both extensively and illicitly, medicinal plants including Coscinium fenestratum or 'Weniwelgheta' and Elattaria cardomomum var. major or wild Cardomum, resins especially from Shorea stipularis or 'Navada' and Vateria copallifera or 'Hal', edible fruits of many speciës like Shorea megistophylla, Shorea disticha, Shorea affinis collectively known as 'Beraliya', V. copallifera or 'Hal', bark of various trees, mushrooms, and numerous other species. ${ }^{7}$

\section{Other Land Uses}

Estates: Abutting some parts the Sinharaja boundary on the southern and more particularly the southeastern and northeastern sides, are tea and rubber plantations, with which the lives of some rural people are closely linked.

These estates, some private and others belonging to the government, are Sinhavalley (tea), Ananda (old rubber) and Polwatta (old rubber) estates within the Galle District, Ratnayake Tea Estate, Neelagiri, Beverley, Manikkawatta, Kalawathuwagala, Sinharaja division of Ensalwatta, all growing tea in the Matara District and Morningside (Cardomum as well), Traquarr (Cardomum as well), and Illumbakanda (Cardomum and forest as well) which also grow tea in the Ratnapura District.

Temples and Hermitages: There are a few temples around the Sinharaja Reserve. They are Sinhalena Tapovanaya (a forest hermitage or 'aranniya') at Kosmulla and the Samangala temple.

\section{Management Strategies Adopted by the Forest Department for the Sinharaja Buffer Zone}

\section{Conservation Management Plans and Recommendations}

The first management plan for the Sinharaja Reserve and its buffer zone was prepared by IUCN, in collaboration with the then Ministry of Lands and Land Development and the Forest Department, in 1986. It was a national effort supported by WWF and IUCN. Phase I of this plan, implemented from 1988 -1991, identified 
the boundary of the forest and demarcated part of it, initiated the buffer zone management programme, provided facilities for visitors, carried out socioeconomic and encroachment surveys, improved the infrastructure, including roads, produced and distributed conservation education material, and embarked on conservation education programmes for the villagers around Sinharaja.

At the completion of Phase I of the original management plan, a revised management plan was drawn up by IUCN, at the request of the Ministry of Environment and Parliamentary Affairs and the Forest Department, and was supported by NORAD. There were 17 recommendations in this revised plan. Those that relate to the buffer zone are the following:

- Complete boundary marking, taking necessary steps to include contiguous privately owned forests, and to exclude long standing encroachments;

- Relocate forest encroachers in the buffer zone;

- Strengthen research on ecological, hydrological and socioeconomic aspects;

- Organize programmes on rural renewal, conservation education and technical interventions;

- Deploy additional staff using community based organizations (CBO) and vigilance groups to strengthen protection;

- Make the necessary legislative and administrative changes to implement the recommendations related to the strict conservation area and the buffer zone;

- Support CBOs, securing their active involvement in the implementation of the management plan and in establishing links with NGOs;

- Enhance accommodation facilities for visitors and provision of competent guides;

- Restrict entry to three entry points;

- Discourage any buffer zone development that might be detrimental to the protection of the reserve.

The strategies adopted for the buffer zone management of Sinharaja could be broadly categorized as follows:

a. Conservation awareness programmes among the village communities

During the initial implementation stages of the Sinharaja Conservation Management Plan (CMP), a number of awareness programmes were organized covering all the 
villages. In these programmes, the objectives of the CMP, the short- and long-term benefits that villagers would receive by collaborating in the implementation activities, and the importance of having village level organizations in order to obtain benefits from the government supported development schemes, were explained. Later, a community level organization named "Sinharaja Sumithuro" or 'Friends of Sinharaja' was formed by village youth in their respective border villages. This organization has participated in various conservation activities.

\section{b. Publicity / mass awareness}

Sinharaja was little known by the general public prior to the implementation of the CMP (up to 1986). Publicity on the attractive features of the Sinharaja MAB Reserve, its biological diversity, its importance as a watershed, historical background and details on the livelihood of the surrounding community, was given through district level awareness programmes, such as via posters, brochures, school-level essay and art competitions, and video documentaries telecast through the national television. Consequently, the number of visitors to Sinharaja increased from an average of 3,500 to about 25,000 per annum within a period of 3-4 years (Table 2).

Table 2: Increase in the numbers of visitors coming to the Sinharaja Man and Biosphere Reserve.

ANNUAL VARIATION OF VISITORS TO SINHARAJA ON THE KUDAWA SIDE

\begin{tabular}{lrrrrrrrrrr} 
Year & 1988 & 1989 & 1990 & 1991 & 1992 & 1993 & 1994 & 1998 & 1999 & 2000 \\
Local & 633 & 369 & 1,673 & 4,171 & 10,365 & 12,617 & 14,562 & 18,844 & 24,208 & 21,426 \\
Overseas & 148 & 114 & 196 & 357 & 808 & 921 & 1,795 & 4,291 & 270 & 2,266 \\
Total & 781 & 483 & 1,869 & 4,528 & 11,174 & 13,538 & 16,357 & 23,135 & 24,478 & 23,692 \\
\hline
\end{tabular}

c. Providing community support

The major activities carried out by Sinharaja Sumithuro (and others as well) are listed below.

- Assisting in upgrading educational facilities in rural schools, by providing library books, accommodation facilities for teachers, liaising with the Education Department to have higher classes in village schools, encouraging and supporting village youth to learn English.

- As the government hospitals are located far away from these villages, organizing a number of health camps, where the services of general medical 
practitioners and specialist consultants were given on a voluntary basis to the villagers. The prescribed medicines were also provided free of charge. Further, those requiring special treatment were helped to visit the nearest and most appropriate general hospital. Spectacles were also given to the needy poorer villagers, through the support of sponsors. This has not only enhanced the village-Forest Department relationship, but the medical officers themselves came to know the forest. In the case of one group of medical officers, their enthusiasm on Sinharaja culminated in including one whole session of their annual sessions to biodiversity. In 1990, 1994 and 1995, health camps were conducted at Sinharaja.

- Improving village roads, by organizing "shramadana" or free labour campaigns, by collaborating with other village societies and by providing material such as cement and hume-pipes where necessary.

d. Adaptive research

Conversion of monoculture Pinus plantations to multiple use forests with high demanding species

Seedlings of Dipterocarps and several other commercial species that are not Dipterocarps, have been planted under different sized canopy gaps, in a part of the buffer zone of Pinus caribaea plantations established around the Sinharaja reserve. This field experiment examined the growth and survival of three groups of species:

- Some primary forest timber species such as Shorea trapezifolia, Shorea megistophylla, Shorea disticha, Dipterocarpus zeylanicus and Shorea stipularis.

- Non-timber forest species such as the rattan Calamus ovoideus, the medicinal plants Coscinium fenestratum and Elettaria cardomum var. major (also a spice plant) and the ground orchid Arundina graminifolia.

- Agricultural export species (domesticated cardamom, pepper, cinnamon and coffee). ${ }^{15}$

In this restoration trial, the performance of species eight years after establishment has been very successful and encouraging. The eco-physiological attributes of the species planted in the different gaps of this trial have also been studied, in order to understand the dynamic changes in the above ground environment accompanying stand growth. ${ }^{2,8,9}$ These results will be used to develop enrichment planting guidelines of these species in Pinus plantations of the hill regions in southwest Sri Lanka. 


\section{Conversion of fern lands}

Other studies have investigated methods of initiating a rain forest succession on fernlands. Removal of the fern rhizome and root mass and raking of the soil have shown the initiation and establishment of pioneer vegetation, in seed of buried and aerial origin. ${ }^{5}$ This study showed how the very aggressive and competitive fern Dicranopteris linearis could be weeded out to encourage other species to grow.

\section{Planting native species under Pinus stands}

The Forest Department has also initiated the introduction of rattan species and other primary forest species in the Sinharaja buffer zone Pine plantations. These enriched stands are also managed at regular intervals.

\section{e. Alternate income-generation and increase in agricultural productivity}

Since the main occupation of the villagers is agriculture, attention was paid to increasing the productivity of their cultivations. As many of them cultivate tea, a number of programmes on soil conservation, use of organic manure, proper use of technical knowledge on nursery practices, as well as maintenance of the cultivation, have been provided in coordination with the Tea Small Holding Development Authority (TSHDA). Access has also been provided for government driven subsidy schemes for upgrading/replanting with VP tea, with the aim of increasing their income.

Kathriarachchi ${ }^{9}$ also surveyed (through personal visits and informal discussions) $50 \%$ of the households in two peripheral villages (Kudawa and Pitakelle) in the northwestern part of the buffer zone, to find out the views of villagers on the initiation of a community based participatory management programme, within the Sinharaja buffer zone, to plant native non-timber forest species. The proportion of households that were enthusiastic to grow Caryota urens and Elettaria cardamomum at Pitakelle was $60 \%$, but at Kudawa only 12 and $29 \%$ respectively.

With the influx of visitors to Sinharaja, the Forest Department initially recruited about 10 youths, on a voluntary basis, from the villages around the main access roads to Sinharaja, and gave them the opportunity to work as visitor guides, thus providing them with a means of livelihood. As these guides are residents of the areas, they have a first hand knowledge of animals and plants in the forest. In addition, they are given a formal training through workshops organized by the Forest Department and the Universities. English classes too have been arranged for them, so that these village youths can communicate, at least to some extent, with overseas visitors. 
The number of visitors, both foreign and local, have now increased considerably and as a result many other economic activities, such as boutiques which supply visitor needs and even a few private accommodation facilities run by the villagers, have arisen in the vicinity of the forest. One private accommodation facility put up by a village entrepreneur can even accommodate large groups of 50 persons and more, and is popular, particularly for birding ecotours.

\section{f. Production of timber and other forest products}

To reduce dependence on the forest, the following activities were initiated with the participation of village societies:

- Distribution of tree seedlings of popular timber species for planting in home gardens, to alleviate, at least to some extent, the future timber needs of the villagers.

- Provided assistance in the establishment of school nurseries, by giving the necessary plants.

- Under-planting Pine plantations with Rattan, which is used for the manufacture of many local handicraft, baskets, etc. and which was usually being cut from the forest.

- Conversion of monoculture Pine plantations, established on barren lands, to broad-leaved Dipterocarpus spp.

g. Promotion and regulation of the non-destructive use of forest products other than timber

Non-destructive extraction of forest products, such as engaging in 'Kitul' (Caryota urens) tapping, collection of wild mushrooms and tree-seeds that have medicinal properties, has been regularized in the buffer zone. The fear that the community had about Forest Officers and other regulatory personnel no longer exists, and villagers are much more cooperative in conservation activities initiated by the FD.

To reduce the quantity of fuelwood used in surrounding villages, all families in the buffer zone were provided with improved stoves/hearths which reduce the amount of fuelwood needed.

\section{Education Centre and Accomodation Facilities}

There is also an education centre, equipped with posters and exhibits, for visitor use at Sinharaja. The Forest Department has reasonably good accomodation facilities, for all group sizes, at Kudawa, a much smaller facility at Pitadeniya in 
the south and a two-roomed facility at Morningside in the east. All these facilities are regularly maintained and improved. A mini-hydropower unit has also been installed at Kudawa for the provision of electricity.

Overnight visitors are also shown films and a slide presentation on Sinharaja, and on request, lectures are given by the officers.

Table 3: Summary of Forest Department support for community based activities around the Sinharaja World Heritage Site in Sri Lanka.

\begin{tabular}{|c|c|c|c|c|}
\hline & Activity/Support & 1998 & 1999 & 2000 \\
\hline \multirow[t]{9}{*}{ * } & Material Assistance to Community Based & & & \\
\hline & $\begin{array}{l}\text { Organisations. Distribution of: } \\
\text { Mobile sheds }\end{array}$ & 26 & 3 & 2 \\
\hline & Hume pipes for road construction to communities in & & & \\
\hline & Galle District & $\checkmark$ & $\checkmark$ & - \\
\hline & Ratnapura District & $\checkmark$ & $\checkmark$ & - \\
\hline & S-lon pipes for drinking water schemes & $\checkmark$ & - & - \\
\hline & Knapsack sprayers: Galle District & 15 & - & - \\
\hline & Fuelwood saving improved stoves & - & $\checkmark$ & - \\
\hline & Bee hives & - & $\checkmark$ & - \\
\hline \multirow[t]{4}{*}{$*$} & $\begin{array}{l}\text { No. of villages that benefited from the voluntary } \\
\text { health camps and clinics conducted: }\end{array}$ & & & \\
\hline & Galle District & 4 & - & 4 \\
\hline & Ratnapura District & 5 & - & 2 \\
\hline & Distribution of spectacles to the needy & - & $\checkmark$ & - \\
\hline * & $\begin{array}{l}\text { No. of brief programmes conducted on } \\
\text { conservation awareness: }\end{array}$ & 45 & 290 & - \\
\hline \multirow[t]{6}{*}{ * } & School Programmes: & & & \\
\hline & No. of schools contacted to organize seminars & 10 & - & - \\
\hline & Organization of art exhibitions in schools & - & - & $\checkmark$ \\
\hline & Provision of library books to rural schools & - & & - \\
\hline & Upgrading accommodation facilities for teachers & - & $\checkmark$ & - \\
\hline & Supporting/encouraging students to learn English & - & $\checkmark$ & - \\
\hline
\end{tabular}

\section{Conclusion}

Over the last quarter century, Sinharaja has gone through many phases. Sinharaja, Sri Lanka's largest comparatively less degraded lowland rainforest, is recognized as a National Heritage Wilderness Area, an International Man and the Biosphere 
reserve, a World Natural Heritage Site (the only one in the island), and a hotspot of biodiversity along with the Western Ghats, because of its biogeographic value and high species endemism with restricted distribution. Its status over the years has changed from a wilderness with traditional mysticism prior to the 1970s, to one of exploitation in the 1970s and again to one of conservation in the late 1970s and up to the present. This jewel in Sri Lanka's protected area network is scientifically so precious that it has taken only a very short time to receive international fame. Yet, the pressures on it from the increasing numbers of visitors and surrounding villagers wanting to grow more and more tea in the perimeter of the forest, and problems associated with it, bring with them new threats to this reserve.

The Sinharaja Reserve is only a relatively small part of a larger extent of the island's biological wealth. The buffer zone of this reserve must be made continuous with those of the remaining reserves in the wet zone of Sri Lanka, if the species and genetic diversity endemic to the island is to be conserved in the long term. In other words; management of Sinharaja in isolation from the rest of the wet zone reserves, is not prudent. They must be managed and conserved as one whole entity. It is this knowledge that has prompted the Forest Department to manage clusters of forests. We hope that in due course this will also lead to linking them through their respective buffer zones and through other reservations like stream, catchment and road reservations, so that this country will have a true and effective network of protected areas, and not a system of isolated, fragmented and ineffective protected areas.

\section{References}

1 Anon. (1993). Management plan for the conservation of the Sinharaja forest (Phase II). pp. 91. IUCN Regional Office, Sri Lanka.

2 Ashton P. M. S., Gunatilleke I. A. U. N. \& Gunatilleke C. V. S. (2000). Restoration of a Sri Lankan rainforest: an eight year review of experimental trials. In: Forests and Society: Role of Research. R. Jandl, M. Devall, M. Khorchidi, E. Schimpf, G. Wolfrum and B. Krishnapillay (Eds.) 2: $2121^{\text {st }}$ IUFRO World Congress, Kuala Lumpur, Malaysia.

3 Ashton P. M. S., Gamage S., Gunatilleke I.A.U.N. \& Gunatilleke C. V. S. (1997). Restoration of a Sri Lankan rainforest using Caribbean pine Pinus caribaea as a nurse for establishing late successional tree species. Journal of Applied Ecology 34: 915 - 925.

4 Bandaratilleke H. M. (1992). Managing the buffer zone in Sinharaja World Heritage Forest. PARKS, The International Magazine Dedicated to the Protected Areas of the World 3(3): 15-19. 
5 Cohen A.L., Sinhakumara B.M.P. \& Ashton P.M.S. (1995). Releasing rain forest succession: A case study in the Dicranopteris linearis fernlands of Sri Lanka. Restoration Ecology. 3(4): 261 - 270.

6 Gamage S. (1998). Feasibility studies on underplanting multiple use species in buffer zone pine plantations of the Sinharaja MAB reserve. M. Phil. Thesis, University of Peradeniya, Sri Lanka.

7 Gunatilleke I.A.U.N. \& Gunatilleke C. V. S. (1993). Under-utilized food plant resources of Sinharaja rain forest in Sri Lanka. In: Food and Nutrition in the Tropical Rainforest: Bicultural Interactions, (C.M. Hladik, A. Hladik, Pagazy, O.F. Linaries \& M. Hadley Eds.) Man and Biosphere Series, 15, UNESCO, Paris and Parthenon Publishing, Carnforth, UK.

8. Kathriarachchi H. S., Tennakoon K. U., Gunatilleke C. V. S. \& Gunatilleke I. A. U. N. (2000). Comparison of some ecophysiological features of two Shorea species in different habitats of Sinharaja forest. In: Proceedings of the Annual Research Sessions 2000. N. Priyantha and D. A. Jayawickrama (Eds.), pp.9. University of Peradeniya, Sri Lanka.

$9 \quad$ Kathriarachchi H. S. (2002). Performance of selected forest species providing non-timber forest products in Sinharaja MAB reserve, Sri Lanka. M. Phil. Thesis, 220pp. University of Perdadeniya, Sri Lanka.

10 Mackinnon J. (1981). Guidelines for the development of conservation buffer zones and enclaves. Nature Conservation Workshop PPA/WWF/FAO, Bogor, Indonesia.

11 Manikrama A. (1993). Assessing Folk Knowledge About Forest Use in the Sinharaja Peripheral villages. Department of Agricultural Economics and Extension, University of Peradeniya, (unpublished).

12 McDermott M., Gunatilleke C.V.S. \& Gunatilleke I.A.U.N. (1990a). The Sinharaja rainforest: conserving both biological diversity and a way of life. The Sri Lanka Forester, 19: $3-22$.

13 McDermott M., Gunatilleke C.V.S. \& Gunatilleke I.A.U.N. (1990b). The Sinharaja rainforest: the compatibility of biological and cultural conservation. The Sri Lanka Forester, 22: 3 - 28.

14 Primack R. B. (2000). A primer of conservation biology. pp.319. Sinauer Associates, Inc. Publishers. 
15 Sunil A.G., Gunatilleke I.A.U.N.,Gunatilleke C.V.S., Ashton P.M.S. \& Gunaratna W.D.L. (1993). Enrichment planting trials for conversion of the buffer zone pine plantations around Sinharaja to productive mixed plantations. Proceedings of the $49^{\text {th }}$ Annual Sessions of the Sri Lanka Association for the Adv. Sci., pp. 49.

16 Wanigasundara W. A D. P., Semasinghe I. \& Ellegala A. (2001). Study of the factors affecting the sustainable management of tea lands in the Sinharaja periphery. Sri Lanka Association for the Advancement of Science Proceedings of the $57^{\text {th }}$ Annual Sessions. Abstract. pp. 270. 